\title{
Note on Sources and Texts
}

The six pairs of speeches from The History of Italy have been taken from the 3rd edition of the translation by Austin Parke Goddard (London: Z. Stuart, 1763). The excerpts have been checked against two Italian editions (Opere, ed. by E. Scarano, Turin: Utet, vols II and III, 1981; and Storia d'Italia, ed. by S. Seidel Menchi, Turin: Einaudi, 1971) and revised accordingly, in both substance and style. I have translated the remaining five pairs from their only available Italian edition (Le cose fiorentine, ed. by R. Ridolfi, Florence: Olschki, 1945, reprinted in 1983; and Opere, vol. VIII: Scritti politici e Ricordi, ed. by R. Palmarocchi, Bari: Laterza, 1933). The speeches have been arranged in chronological order according to the time of the events they address - an order that does not always coincide with the time of their composition; the pairs of speeches in Chapters 9 and 10 were written before all the others, in 1525 . 